\title{
Nasopharyngeal Cancer TNM Finding v8
}

National Cancer Institute

\section{Source}

National Cancer Institute. Nasopharyngeal Cancer TNM Finding v8. NCI Thesaurus. Code C132792.

A finding about one or more characteristics of nasopharyngeal cancer, following the rules of the TNM AJCC v8 classification system. Epithelial tumors of the nasopharynx are staged using this staging system. Mucosal melanoma, lymphoma, and sarcoma of soft tissue, bone, and cartilage are not included in this classification. (from AJCC 8th Ed.) 